\title{
AN APPROACH TO SELECT PARTNERSIN OVER-THE-TOP INITIATIVES
}

\author{
Jemy Vestius Confido a, Dermawan Wibisono $^{b}$, Yos Sunitiyoso ${ }^{c}$ \\ ac Bandung Institute of Techonology, Jakarta,Indonesia \\ b Pertamina University, Jakarta,Indonesia \\ Corresponding email: jemy.confido@sbm-itb.ac.id
}

\begin{abstract}
Over-The-Top (OTT) players aggressively provide applications and contents including potential substitutes for communication services provided by Communication Service Providers (CSPs). To counter this challenge, CSPs have to provide various OTT services under limited capabilities and may consider collaborating with OTT players. This research intends to establish an approach to select OTT partner using a combination of SWOT analysis and reverse logic of interfirm rivalry model. The approach deploys in-depth interviews involving top-level executives from a leading CSP in South East Asia, questionnaires distributed to strategic-level business managers and two FGD sessions as part of Group Model-Building and action research implementation. The research finds that a checklist table modified from the conventional SWOT analysiscombined with awareness, motivation and capability (AMC) aspects from the interfirm rivalry model is very helpful to assist business manager in assessing potential partners for CSPs trying to collaborate with OTT players.
\end{abstract}

Keywords: Communication Service Provider (CSP), Interfirm Rivalry, Over-The-Top (OTT) Player, SWOT.

\section{Introduction}

In an effort to compete with Over-The-Top (OTT) services, Communication Service Providers (CSPs) havebeen providing their own OTT services using various business model such as two-sided markets model (Zhao, 2011; Armstrong, 2006; Rysman, 2009), freemium (Martin, 2012; Needleman and Loten 2012) or market capitalization (Morgan Stanley, 2014; Gupta and Mela, 2008).However, given limited capability in conducting OTT business, CSPs may need to choose three possible development strategies: create their own OTT services, collaborate with OTT players or captureexisting OTTbusiness. The last two options involves some degree of partnership whichis not easy to deal with in the very dynamic environment. In the effort of partnership, many previously bounded two companies may turn their cooperation into competitionfor manyreasons.Clearly, more comprehensive understanding towards competition or cooperation potential is very essential to establish sustainable partnership. The conventional SWOT analysis has addressed this kind of potentials, but only from theperspective of company performing the analysis. The SWOT analysis also lacks attention towardsreason and motivation for taking certain initiatives. On the other hand, a newer interfirm rivalry concept using awareness, motivation and capability (AMC) approach has emerged and drawn attention from both academic and practice world which can be explored to invent simpler and more reliable tool for partner selection.

In a situation where a CSP is entering an OTT business throughpartnership strategy with OTT players, this research intends to address the following issues: 
1. How can a CSP effectively manage OTT partner selection process to maximize possibility of successful partnership?

2. Will it be helpful to providea specific OTT partner selection approach in this case?

3. Can interfirm rivalry concept combined with SWOT analysis become the foundation of OTT partner selection approach?

\section{Literature Review}

Porter (1980) suggests that behavior of an industryshould be captured at interfirm level because interactivity between competing companies is very dynamic and involves mutual interdependentstrategies.Many ideas have already resulted from researches on interfirm rivalry that could explain rivalry profile and behavior in more specific ways (Baum and Korn, 1994; Chen and MacMillan, 1992; MacMillan, McCaffery, and van Wijk,1985; Smith, Grimm and Ganon, 1992). Ideas from interfirm rivalry concept could be modified using its reverse logic to assess cooperation potential between CSPs and OTT players. Interfirm rivalry is emphasized as the conduct of individual firms while competition is considered as properties of the industry or marketing structure in the broader sense (Baum and Korn, 1994; Caves, 1984; Hannan and Freeman, 1989; Jacobson, 1992). Interfirm rivalry can be more effectively analyzed at individual level by studying the exchange of moves or action and countermoves or response (Caves, 1984; Porter, 1980; Smith, Grimm and Ganon, 1992).According to Chen, Smith and Grimm (1992), iteration between action and response is consequential because at individual level competitive engagement occurs. In the interfirm rivalry context, a company's specific competitive move, such as introducing a new product or entering a new market is considered as an action or attack (Chen and Hambrick,1995; Chen and MacMillan, 1992).The idea of interfirm rivalry has been initiated in the assessment of competitor's strengths and weaknesses with respect to particular focal firm as addressed by Porter (1980) who suggests a company initiating an attack should take into account the defender's overall market and resource profiles in predicting attack and response. The importance of a competitive attack has been widely acknowledged in such concepts as first-mover advantage (Lieberman and Montgomery, 1988) and competitive initiative (MacMillan, 1982) which force competitors to take reactive position and this explains whythe ultimate effectiveness of an action depends largely on responses of defenders (Chen and MacMillan, 1992; Smith, Grimm and Gannon, 1992; D'Aveni, 1994). This view reminds us again that key feature of rivalry is its dynamic and interactive nature (Schelling, 1960; Weigelt and MacMillan, 1988).

The research holds the hypothesis that between CSPs and OTT players, tendency to avoid action and response indicates cooperation potential. Likelihood of attack and response can be predicted using three drivers of competitive behavior:awareness, motivation, and capability. In general, awareness is likely to be increased by both market commonality and resource similarity. Market commonality will affect the motivation of a company to attack (or respond); resource similarity will influence attack (or response) capability(Chen,1996). Competitors interacting in multiple market would be less motivated to compete aggressively in a market because of their awareness towards possible retaliation across various market (Barnett, 1993; Gimeno, 1994; Ma and Jemison, 1994). Thus, companies that are close competitors may not be the most intense rivals (Baum and Korn, 1994).Gimeno and woo (1994) argue that the more market companies havecompetition, the less aggressive they are to each other resultingin less rivalry. Chen (1996) proposes Proposition 1a which implies two companies with high market commonality will be less likely to initiate an attack against each other. Porter (1980) notes market commonality implication for response by stating that companies are mutually dependent. Pfeffer (1982, 1987) and Pfeffer and Salancik(1978) also point to the significance of market interdependence whichis closely related to market commonality.Decision makers are more likely to respond to threats (Dutton and Jackson,1987) especially if the threats are initiated by a rival with high market commonality (Chen and MacMillan, 1992) or the extent to which the companyheavily relies for revenues on the markets.Based on these thoughts, Chen (1996) proposes Proposition 1b which implies 
that two companies with high market commonality will tend to respect each other's position and avoid conflict.

Amit (1988) and Weigelt (1988) suggest that a defender's potential response is a matter of great concern for an attacker. Defending company with strategic endowments comparable to those of the initiator will be the most capable of effective response. Chen (1996) formulates this conclusion in the Proposition 2a which implies that two companies with greater resource similarity will less likely initiate attack against each other. Response of a company is determined mainly by its capability which is very likely to be conditioned by its degree of resource similarity with the initiator. Ideally, a company would like to initiate a competitive challenge that would fully utilize its resource-based advantage which is the heterogeneous asset bases (Rumelt, 1984) in order to prevent competitive imitation (Collis, 1991). If the response will require substantial resource commitment and major organizational restructuring, rivals are less likely to respond and will respond more slowly (Chen and MacMillan, 1992; Chen and Miller, 1994). Companies will be more motivated and capable to react easily to situations that evoke routine responses (Allison, 1971). Defenders that are more similar to the attacker in their strategic resource endowments will have the greatest potential and capability for retaliation. Chen (1996) proposes Proposition $2 b$ which implies that two companies with greaterresource similarity will tend to respect each other's capability and avoid conflict.

Market interdependence is the most significant aspect for effecting competitive behaviors (Gimeno and Woo, 1994). Companies that have the highest market commonality are the most direct and mutual recognized competitors. In a competitive situation, a company must first be motivated to act or react, regardless of its capability. Motivation is a necessary condition and prerequisite for behaviors, and it is a more direct and a stronger predictor of interfirm rivalry than its capability (Chen and Miller, 1994). This argument is the basis for Proposition 3 (Chen 1996) which implies that market commonality is stronger than resource similarity in predicting competitive attack and response.

Tversky (1977) explains that relationship between two objects do not always follow symmetric relation such as if A is B's primary competitor, it does not necessarily follow that B is A's primary competitor. Collis (1991) argues that each company would approach rivals and competition very differently. From this explanation and argument, Chen (1996) derives Proposition 4a which implies that relationship between rivals is very likely asymmetry since any two companies usually have different degrees of market commonality and resource similarity.Chen (1996) also uses asymmetry consideration as the basis for Proposition $4 \mathrm{~b}$ which implies that competitive asymmetry in market commonality and resource similarity causes the likelihood that Company A will attack Company B will differ from the likelihood that Company B will attack Company A. Similarity is also true for the response likelihood.

For decades, academicians and managers have been using SWOT analysis to conduct environmental scanning and make internal analysis. Analysts performing the SWOT analysis usually perceive competition at industry level and do not consider motivation behind attacks and responses. However, in comparison to the AMC, SWOT makes more distinctions between strengths and weaknesses on one hand and differences between opportunities and threats on the other hand. In OTT partner selection, SWOT can be used to more specifically assess paired competition profile between CSPs and OTT players. Table $\mathbf{1}$ is constructed to summarize the comparison between AMC and SWOT.

Table 1: Comparison between AMC and SWOT

\begin{tabular}{|c|l|l|}
\hline Aspects & \multicolumn{1}{|c|}{ AMC } & \multicolumn{1}{c|}{ SWOT } \\
\hline Awareness & Awareness of Market Commonality and Resource & $\begin{array}{l}\text { Awareness towards opportunities and threats against } \\
\text { other players in general or particular (paired }\end{array}$ \\
\hline
\end{tabular}




\begin{tabular}{|c|c|c|}
\hline & Similarity with particular players. & comparison). \\
\hline Motivation & $\begin{array}{l}\text { Motivation to attack or to respond towards particular } \\
\text { playerwhich could be driven by market commonality. }\end{array}$ & \\
\hline Capability & $\begin{array}{l}\text { Capability to attack or to respond towards particular } \\
\text { player would be influenced by resource similarity. }\end{array}$ & $\begin{array}{l}\text { Capability is categorized as strengths or weaknesses } \\
\text { against other players in general or particular (paired } \\
\text { comparison). }\end{array}$ \\
\hline
\end{tabular}

Source:Result of this research

Both SWOT analysis and interfirm rivalry AMC have their own advantages. SWOT analysis can be used to assess overall competition profile as well as profile of particular company in paired comparison mode. AMC, on the other hand, is very powerful to assess profile and behavior of individual company. This research proposes to construct a new form which combines advantages of SWOT analysis and interfirm rivalry AMC with its competitive analysis (market commonality and resource similarity) and competitive behavior (AMC) as shown in the Table 2 below. The form consists of three parts. The upper part is to identify name and type of the company, i.e. a CSP or an OTT player, and OTT business the analysis is made for. The middle part is intentedto assess the awareness, capability and motivation of the company being analyzed. Various factors related to each aspect are listed accordingly. For instance, awareness includes market regions, market segments, services, customer behavior, tehcnology and regulation. Capability includes network infrastructure, customer base, portfolio, platform, technical people and business network. Finally, motivation includes market commonality, resource similarity, likelihood of attack and likelihood of response. Business manager can add more factors under awareness and capability if necessary. The middle part is filled by providing checks $(\sqrt{ })$ to the relevant column or providing scores according to preagreed criteria. Total checks or scores can be summed up to determine if the candidate tends to provide opportunities, threats, strengths or weaknesses which in turn indicate its potential as either competitor, collaborator or capture target. The form is to be filled by comparing the CSP conducting the analysis against each candidate.

Table 2:ProposedAMC and SWOT Form to Assess Potential Partners

\begin{tabular}{|l|l|l|l|}
\hline Company Name & \multicolumn{2}{|l|}{ CSP } & \multicolumn{2}{|l|}{ OTT } \\
\hline Company Type & \multicolumn{1}{|l|}{$\begin{array}{l}\text { Awareness of } \\
\text { Opportunities }\end{array}$} & Awareness of Threats \\
\hline OTT Business being Analyzed & & \\
\hline Awareness & External Factors & & \\
\hline & $\begin{array}{l}\text { Awareness of OTT Market } \\
\text { Regions }\end{array}$ & & \\
\hline & $\begin{array}{l}\text { Awareness of OTT Market } \\
\text { Segments }\end{array}$ & & \\
\hline & Awareness of OTT Services & & \\
\hline & Awareness of Customer Behavior & & \\
\hline & Awareness of Technology & & Capability Weakness \\
\hline & Awareness of Regulation & & Factors \\
\hline & Other factors: & & \\
\hline & Other factors: & & \\
\hline & Overall External Factors & & \\
\hline & Internal Factors & & \\
\hline & Network Infrastructure Capability & & \\
\hline & Customer Base Capability & & \\
\hline & OTT Portfolio Capability & & \\
\hline & OTT Platform Capability & & \\
\hline & OTT Technical People Capability & & \\
\hline & OTT Business (Network) & & \\
\hline & Other factors: & & \\
\hline & Other factors: & & \\
\hline & & & \\
\hline
\end{tabular}




\begin{tabular}{|l|l|l|}
\hline \multicolumn{1}{|c|}{ Overall Internal Factors } & High & Low \\
\hline Motivation & & \\
\hline - Degree of Market Commonality & & \\
\hline - Degree of Resource Similarity & & \\
\hline - Likelihood of attack (using OTT services) & \\
\hline - Likelihood of response (using OTT services) & & \\
\hline The Player's Potentials & & \\
\hline \multicolumn{2}{|c|}{ Competitor } & Collaborator \\
\hline
\end{tabular}

Source:Result of this research

A CSP could have several partners depending onmarket size, technological factors and other aspects such as regional permit.To assess multi-partners situation, market commonality and resource similarity can be used to map candidates for their classification either asdirectly potential competitors, collaborators or capture targetsas shown in Table 3.

Table 3: The Use of Market Commonality and Resource Similarity to Assess Competition and Collaboration Potential

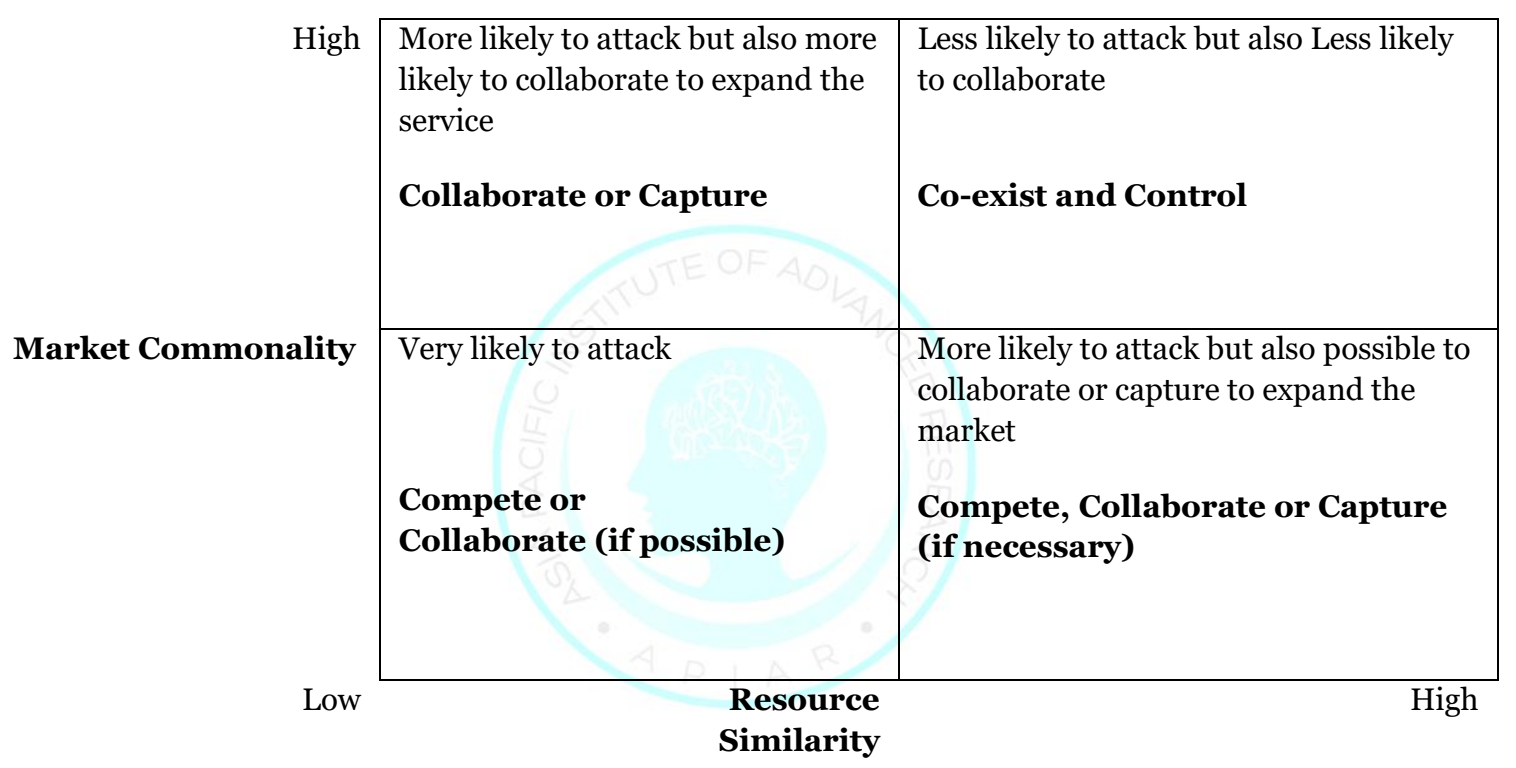

Source:Result of this research

\section{Methodology}

The research adopts Group Model-Building (Vennix et al. 1992, Vennix, 1996, Andersen and Richardson 1995, Andersen and Richardson, 1997, Andersen, Richardson, Vennix, 1997) to verify if combination of SWOT analysis and AMC from interfirm rivalry concept can be used toselect OTT partners. The research is conducted at one of the largest CSP in South East Asia which has OTT initiatives both at holding and subsidiary level.Data collectionof the research includes in-depth interviews, questionnaires, and Focus Group Discussions (FGD) which involve respondents and participants who have been working on more than fifty OTT projects or initiatives in total. The in-depth interview involves top-level executives while both questionnaires and FGDs involve strategic-level business managers. Three primary issues are addressed in the in-depth interview: strategy consideration, development consideration and partnership consideration. Findings from the in-depth interview are thenfollowed up by questionnaires at strategic-level which operates the businessto confirm the needs for a systematic approach in partnerselection.

Selected strategic-level respondents are invited to participate in the FGD to assess and try the newly constructed partner selection form. Participants are selected based on their acceptance towards the new approach. Their position either at group or subsidiary level and 
whether they are managing portfolio or managing initiatives are also considered. The FGD consists of two sessions which are intended to assess opinions of participants toward the partner selection form andto use the form according to initiatives theyare currently working on. Prompt feedbacks from participants are solicited afterward.

\section{Research Findings}

Seven top-level executives are in-depth interviewed to obtain their considerations on partner selection in OTT business. According to one top-level executives, when the CSP chooses to collaborate, it is mediating other parties to embrace and align with its strategy. Top-level executives consider position of the CSP in the OTT business as the basis for development strategy. Primary aspect which determines position of the CSP is its capability to provide and to market an OTT service. In general, the top-level executives categorize the company's capability in various OTT businesses as not capable, partly capable and fully capable.They alsoconcern that in regard to development strategy, either the CSP decides to collaborate with or capture an OTT player, it will get involved with a quite complex partnership situation. The top-level executives consider to avoid investment when the OTT initiative is still uncertain due to a lack of capability or early stage of the development. As the OTT initiative becomes more certain and the development stage becomes mature, the CSP will be more willing to invest and the development strategy may change from collaboration to capture which associated with more ownership share.

The CSP must consider its own portfoliowhen selecting a partner. For instance, if the service involves providing platform, then the CSP prefers to capture or create. One top-level executive explains that the CSP has to previously decide if it will have one partner, closed platformwith several limited partners or open platform. Three top-level executives also consider region or number of countries in which partners operate and their internal capability. The CSP also needs to consider strong points of each partner such as reputation in OTT business, company's health and opportunity for further enhancement. One top-level executive reminds that finding a partner which holds those attributes is very difficult. One top-level executive highlights that passionate founder and fit culture arepreferrable. Whether candidates will potentially become competitors or not is very critical. Finally, price is included as one determinant factor in partner selection. Higher price may be compensated with financialdeal such as first call option. The CSP tends to become more dominant in ownership share to secure its portfolio. If the initiative is still at early stage, the CSP will request aright to become dominantshareholder in the future. The CSP usually deployswinwin approach with one partner but keep non-exclusivity for additional partners.Two toplevel executives also consider impact of the acquisition towards market value of the CSP.

When considering potential partners, three top-level executives prefer to assessthree best candidates and then focus on one partner. One top-level executive argues that higher chance of success requires fewer number of partners and vice versa. Another top-level executive implies that the CSP must start from users' needs. If no partner can fulfill all needs, then more partners should be considered.The CSP must also consider its capability to attract potential partners by having its own key advantages such as large customer base and wide network coverage. On the other hand, the CSP also must assess which OTT players will become the winner andtake larger market share. Finally, one top-level executive expects to have a tool to find partners and to make dealsespecially with global partner.Table 4 below depictssummary of the in-depth interview categorized into three concerns: development strategies, partner selection and partner management. 
Table 4: Summary of the In-Depth Interview

\begin{tabular}{|c|c|}
\hline \multicolumn{2}{|c|}{ Concerns on Development Strategies } \\
\hline General Conditions & $\begin{array}{l}\text { Considered OTT services must both fit with the strategy and promise } \\
\text { attractive market. If only one condition is met then collaborate. }\end{array}$ \\
\hline Portfolio & $\begin{array}{l}\text { If the OTT initiative involves platform or posseses many } \\
\text { interdependencisthen capture or create is preferred. }\end{array}$ \\
\hline Market Structure & $\begin{array}{l}\text { If market is complex with many competitors then avoid competition. If } \\
\text { there is only few dominant players then capture the strongest one (one } \\
\text { partner). If there are many dominant players then provide platform for } \\
\text { everyone (open platform). Adjustment to multi partners can be made } \\
\text { accordingly. }\end{array}$ \\
\hline Ecosystem & $\begin{array}{l}\text { If ecosystem is not established then choose to collaborate at smaller } \\
\text { investment portion. }\end{array}$ \\
\hline Concept & $\begin{array}{l}\text { For proven concept, create or capture is more adviseable and for not } \\
\text { proven concept, collaborate is more adviseable. }\end{array}$ \\
\hline Time Opportunity & $\begin{array}{l}\text { If longer time is available then create. If only shorter time is available } \\
\text { then collaborate or capture. }\end{array}$ \\
\hline Internal Capability & $\begin{array}{l}\text { Internal capablity to provide and to market OTT services: if none then } \\
\text { capture, if partly then collaborate, if fully then create. }\end{array}$ \\
\hline Risk & $\begin{array}{l}\text { If higher risk is associated then collaborate, if lower risk is associated } \\
\text { then create or capture. }\end{array}$ \\
\hline Confidence Level & $\begin{array}{l}\text { If confidence level of the manager towards the initiative is high then } \\
\text { create or capture, otherwise, create. }\end{array}$ \\
\hline Market Value & $\begin{array}{l}\text { If the acquisition is predicted to increase market value then capture is } \\
\text { preferred. Otherwise, consider create or collaborate. }\end{array}$ \\
\hline \multicolumn{2}{|l|}{ Concerns on Partner Selection } \\
\hline Number of Partners & More functionalities require more number of partners. \\
\hline Number of Candidates & $\begin{array}{l}\text { Higher chance of success to make a deal requires less number of } \\
\text { candidates. }\end{array}$ \\
\hline Likelihood to become the Winner & $\begin{array}{l}\text { The more likely a candidate becomes the winner in the market, the more } \\
\text { likely it becomes a partner. }\end{array}$ \\
\hline Partner'sReputation & $\begin{array}{l}\text { Bigger footprint, stronger capability, healthier company, more potentials } \\
\text { for future enhancement, more passionate founder, less-likely to become } \\
\text { competitor are preferred. }\end{array}$ \\
\hline Price of Partnership & $\begin{array}{l}\text { Lower price, flexible scheme, first call option, bigger percentage of share, } \\
\text { non exclusivity right, post acquisition plan and higher market value are } \\
\text { preferred. }\end{array}$ \\
\hline \multicolumn{2}{|c|}{ Concern on Partner Management } \\
\hline Maturity Level & Spend less at infant stage and more at mature stage. \\
\hline Alternative Approaches & $\begin{array}{l}\text { New approaches such as open innovation, start up invitation and internal } \\
\text { organic initiatives are considered to minimize associated risks in } \\
\text { emerging services. }\end{array}$ \\
\hline
\end{tabular}

Source: Result of this research

In general, top-level executives expect to have a moresystematic approach in making decision on development strategy and partnerselection. Results from the in-depth interview is then confirmed with questionnaireswhich indicate that almost all strategic-level executives agree to use standard procedure or guideline to make decision on development strategy and partner selection.Eight respondents from strategic level who consistently agree that the guideline is needed and expect to follow that guideline are then selected to participate in two FGD sessions. Participants' roles and responsibilities pertaining to the OTT service development process including their positions whether at holding or subsidiary level are also considered in the selection. The FGDs are conducted in two different sessions. In the first session, all respondents reconfirm that combination of AMC and SWOTis fit to partner selection situation. The second session furthermore exercise the AMC - SWOT partner 
selection form using Group Model-Building approach. In this session, respondents are requested to use the form to evaluate current partners on initiatives they are currently working on and then are asked for their opinions which resulting these following points:

- The AMC - SWOT form can be used to evaluate partners on the on going OTT initiatives and to analyzetheir behaviors.

- The form is considered as working model to guide the mapping of each partner whilethe tableof resource similarity and market commonality is considered as presentation model.

- The form is very useful for project managers who have to manage many OTT partnersinvolving three critical stages: selection, implementation and evaluation.

\section{Result Analysis}

The respondents show great appreciation and give positive feedback toward the AMC SWOT form and the resource similarity - market commonality map. Theyperceivethe form as both useful and easy to use. The form is expected to become part of standard procedurein selecting OTT partner. Using the AMC - SWOT form, the respondents can identify characteristics of potential partners for further collaboration and even five respondents can specifically evaluate partner candidates and make effective recommendation.

Insights from the top-level pertaining to partner selection as shown in Table 4 also need to be considered in the AMC - SWOT form. There are three aspects to be included in the revised AMC - SWOT form which are: likelihood to become the winner, partner's reputation and price of partnership. Likelihood to become the winner implies that the candidate has a big possibility to become market leader in the future. Similarly, other aspects of reputation such as area of operation, company's financial health, future potential, founder's profile, capability and likelihood to become a threat are deeply considered when the CSP is assessing candidates.The last two aspects have already been covered in the initial AMC - SWOT form and will not be added in the revised form. Future potential aspect will be combined with the likelihood to become the winner since the two involve prediction towards future candidate's achievement and result. Finally, price to realize partnership is also considered including other related factors such as flexibility, exclusivity, estimation of market value after the acquisition and post acquisition plan which will not be included in the revised form because it involves discretion from the top-level executive. These three aspects are included in the revised AMC - SWOT form as depicted in the Table 5. Likelihood to become the winner and future potential are included in motivation factors since both of them involve some degree of future prediction. Accordingly, partner's reputation is included in the capability factors since it represents capability of the partner and its related attributes. Finally, price of partnership is included under the awareness factorbecause partner's awareness will influence the price and distribution of the additional three aspects should be balanced into the three factors.

Table 5:Revised Version of AMC and SWOT Form to Assess Potential Partners

\begin{tabular}{|l|l|l|l|}
\hline Company Name & \multicolumn{2}{|l|}{ OTT } & \multicolumn{1}{|l|}{} \\
\hline Company Type & CSP & \multicolumn{1}{|c|}{ Awareness of Threats } \\
\hline OTT Business being Analyzed & $\begin{array}{l}\text { Awareness of } \\
\text { Opportunities }\end{array}$ & \\
\hline Awareness & External Factors & & \\
\hline & Awareness of OTT Market Regions & & \\
\hline & Awareness of OTT Market Segments & & \\
\hline & Awareness of OTT Services & & \\
\hline & Awareness of Customer Behavior & & \\
\hline & Awareness of Technology & & \\
\hline & Awareness of Regulation & & \\
\hline & $\begin{array}{l}\text { Price of Partnership: acquisition } \\
\text { price/collaboration expenses, } \\
\text { flexibility, exclusivity, estimated } \\
\text { market value }\end{array}$ & & \\
\hline & Other factors: & & \\
\hline & Other factors: & & \\
\hline
\end{tabular}




\begin{tabular}{|c|c|c|c|}
\hline & Overall External Factors & & \\
\hline Capability & Internal Factors & $\begin{array}{l}\text { Capability Strength } \\
\text { Factors }\end{array}$ & $\begin{array}{l}\text { Capability Weakness } \\
\text { Factors }\end{array}$ \\
\hline & Network Infrastructure Capability & & \\
\hline & Customer Base Capability & & \\
\hline & OTT Portfolio Capability & & \\
\hline & OTT Platform Capability & & \\
\hline & OTT Technical People Capability & & \\
\hline & OTT Business (Network) Capability & & \\
\hline & $\begin{array}{l}\text { Reputation: area of operation, } \\
\text { company's health, founder's profile }\end{array}$ & & \\
\hline & Other factors: & & \\
\hline & Other factors: & & \\
\hline & Overall Internal Factors & & \\
\hline \multicolumn{2}{|l|}{ Motivation } & High & Low \\
\hline \multicolumn{4}{|c|}{ - Degree of Market Commonality } \\
\hline \multicolumn{4}{|c|}{ - Degree of Resource Similarity } \\
\hline \multicolumn{4}{|c|}{ - Likelihood of attack (using OTT services) } \\
\hline \multicolumn{4}{|c|}{ - Likelihood of response (using OTT services) } \\
\hline \multicolumn{4}{|c|}{$\begin{array}{l}\text { - Likelihood to become the winner and future } \\
\text { potential }\end{array}$} \\
\hline \multicolumn{4}{|c|}{ The Player's Potentials } \\
\hline & Competitor & Collaborator & Capture Target \\
\hline
\end{tabular}

Source:Result of this research

Upon completing the FGD, the respondents are asked to fill inquestionnaire feedback based on the Technology Acceptance Model (TAM) by Davis (1989) with some modification to make it more relevant to the situation.Almost all respondents strongly agree that the use of the AMC - SWOT form supports critical aspects of their job in selecting OTT partners, increases their productivity in dealing with OTT partners and enhances their effectiveness in managing OTT partners.Almost all respondents strongly agree that the formis not cumbersome to use, not frustrating to fill in, easy to learn and easier to get the job done.

\section{Recommendations and Contributions}

This research consists of two parts which are assessing the need for OTT partner selection approach and testing the proposed OTT partner selection approach. The first part explicitly answers the first research question which can be concluded that OTT partner selection process can be more effectively managed with the presence of a systematic approach that considers relevant attributes of the candidates. Finally, to answer the third research question, the second part of the research concludes that combination of AMC and SWOT provides comprehensive perspective toward partner's attributes as well as its behaviorswhich in turn will help project managers in performing partner selection.

Insights from top-level executives pertaining partner selection are comprehensive and solid, however these valuable information need to be structured for further use. From the in-depth interview, questionnaires and two assessment rounds, it can be empirically concluded that top-level insights must be put into guidance for strategic-level implementations to ensure alignment between the two. Results from the two FGD sessions imply that more hands on and formal process on the AMC - SWOT form implementation is required to ensure understanding and commitment from project managers.Further research is needed to validate the use of this form in general. Researchimprovement could be made inthese three areas: extracion of top-level insights, qualification of each partner's attributes and discretion of project managers to make final call on partner selection.

This research contributes both to practice and research world. To the practice world, this researchprovides new approach on how to evaluate and select OTT partners using combination of AMC and SWOT. To the research world, this researchencourages more exploration on systematic approach in performing OTT partner selection. Application of this AMC - SWOT form to other non OTT business situations could also be further explored. 


\section{References}

i. Allison, G., 1971. Essence of Decision:Explaining the Cuban Missile Crisis, Boston: Little Brown.

ii. Amit, R., Domowitz, I. \& Fershtman, C., 1988. Thinking One Step Ahead. The Use of Conjectures in Competitor Analysis, Strategic Management Journal, Volume 9, pp. 431-442.

iii. Andersen, D. \& Richardson, G., 1997. Scripts for Group Model Building. System Dynamics Review, 13(2), pp. 107-129.

iv. Andersen, D., Richardson, G. \& Vennix, J., 1997. Group Model Building. Adding More Science to the Craft, System Dynamics Review, 13(2), pp. 187-201.

v. Armstrong, M., 2006. Competition in Two-Sided Markets. Rand Journal of Economics, 37(3), pp. 668-691.

vi. Barnett, W., 1993. Strategic Deterrence among Multiple Point Competitors. Industrial and Corporate Change, Volume 2, pp. 249-278.

vii. $\quad$ Baum, J. \& Korn, H., 1994. 1994.Competitive Dynamics of Interfirm Rivalry.Linking Structural Conditions of Competition to Patterns of Market Entry and Exit. Academy of Management Journal.

viii. Caves, R., 1984. Economic Analysis and Quest for Competitive Advantage. Papers and Proceedings the 96th Annual Meeting of the American Economic Assosiation, 74(2), pp. 127132.

ix. Chen, M., 1996. Competitor Analysis and Interfirm Rivalry: Toward a Theoretical Integration. The Academy of Mangement Review, 21(1), pp. 100-134.

x. $\quad$ Chen, M. \& Hambrick, D., 1995. Speed, Stealth, and Selective Attack: How Small Firms Differ from Large Firms in Competitive Behavior. Academy of Management Journal, Volume 38, pp. 453-482.

xi. Chen, M. \& MacMillan, I., 1992. Nonresponse and Delayed Response to Competitive Moves: The Roles of Competitor Dependence and Action Irreversibility. Academy of Management Journal, Volume 35, pp. 539-570.

xii. Chen, M. \& Miller, D., 1994. Competitive Attack, Retaliation and Performance: An ExpectancyValence Framework. Strategic Management Journal, Volume 15, pp. 85-102.

xiii. Chen, M., Smith, K. \& Grimm, C., 1992. Action Characteristics as Predictors of Competitive Responses. Management Science, Volume 38, pp. 439-455.

xiv. Collis, D., 1991. A Resource-Based Analysis of Global Competition: The Case of the Bearings Industry. Strategic Management Journal, Volume 12, pp. 49-68.

xv. $\quad$ D.FAndersen \& Richardson, G., 1995. Teamwork in Group Model-Building. System Dynamics Review, 11(2), pp. 113-137.

xvi. D'Aveni, R., 1994. Hypercompetition: Managing the Dynamics of Strategic Maneuvering, New York: Free Press..

xvii. Davis, F., 1989. Perceived Usefulness, Perceived Ease of Use, and User Acceptance of Information Technology. MIS Quarterly, Volume 13, pp. 319-340.

xviii. Dutton, J. \& Jackson, S., 1987. Categorizing Strategic Issues: Links to Organizational Action. Academy of Management Review, Volume 12, pp. 76-90.

xix. Gimeno, J., 1994. Multipoint Competition, Market Rivalry and Firm Performance: A Test of theMutual Forbearance Hypothesis in the U.S. Airline Industry, 1984-1988, West Lafayette: Purdue University.

xx. Gupta, S. \& Mela, C., 2008. What is a Customer Worth?. Harvard Business Review, November 
xxi. Hannan, M. \& Freeman, J., 1989. Organizational Ecology, Cambridge, MA: Harvard University Press.

xxii. J.Gimeno \& Woo, C., 1994. Hypercompetition in a Multimarket Environmental-The Role of Strategic Similarity and Multimarket Contact on Competitive De-Escalation. Organization Science, Volume 7, pp. 322-341.

xxiii. Lieberman, M. \& Montgomery, D., 1988. First Mover Advantages. Strategic Management Journal, Volume 9, pp. 41-58.

xxiv. $\quad$ MacMillan, I., 1982. Seizing Competitive Initiative. Journal of Business Strategy, 2(4), pp. 4347.

xxv. MacMillan, I., McCaffery, M. \& Wijk, G., 1985. Competitor's Responses to Easily Imitated New Products: Exploring Commercial Banking Product Introductions. Strategic Management Journal, Volume 6, pp. 75-86.

xxvi. Ma, H. \& Jemison, D., 1994. Effect of Spheres of Influence and Differentials in Firm Resources and Capability on the Intensity of Rivalry in Multiple Market Competition, Dallas, TX.: s.n.

xxvii. $\quad$ Needleman, S. \& Loten, A., 2012. When Freemium Fails. Wall Street Journal.

xxviii. Pfeffer, J., 1982. Organizations and Organization Theory, Cambridge, MA: Harper \& Row.

xxix. Pfeffer, J., 1987. A Resource Dependence Perspective on Intercorporate Relation. In: M.SMizruchi \& M. Schwartz, eds. Intercorporate relations: The Structure Analysis of Business. Cambridge, MA: Cambridge University Press, pp. 25-55.

xxx. Pfeffer, J. \& Salancik, G., 1978. The External Control of Organizations: A Resource Dependence Perspective, New York: Harper \& Row.

xxxi. Porter, M., 1980. Competitive Strategy: Techniques for Analyzing Industries and Competitors, Competitors: Free Press.

xxxii. R.Jacobson, 1992. The “Austrian" School of Strategy. Academy of management review, Volume 17, pp. $782-807$.

xxxiii. Rumelt, R. P., 1984. Toward a Strategic Theory of the Firm. In: R. Lamb, ed. Competitive Strategic Management. Englewood Cliffs, NJ: Prentice Hall, pp. 556-570.

xxxiv. Rysman, M., 2009. The Economics of Two-Sided Markets. Journal of Economic Perspectives, 23(9), pp. 125-143.

xxxv. Schelling, T., 1960. The Strategy of Conflict, Cambridge, MA: Harvard University Press.

xxxvi. Smith, K., Grimm, C. \& Gannon, M., 1992. Dynamics of Competitive Strategy, Newbury Park, CA: Sage.

xxxvii. Tversky, A., 1977. Features of Similarity. Psychological Review, Volume 84, pp. 327-352.

xxxviii. Vennix, J., Anderson, D., Richardson, G. \& J.Rohrbaugh, 1992. Model-Building forGroup Decision Support: Issues and Alternatives in Knowledge Elicitation. European Journal of Operational Research, 59(1), pp. 28-41.

xxxix. Vennix, J. M., 1996. Group Model-Building: Facilitating Team Learning Using System Dynamics, Chichester: John Wiley \& Sons.

xl. W.Zhao, 2011. Two-Sided Markets Model and Its Applications, s.l.: Stanford University.

xli. Weigelt, K. \& MacMillan, I., 1988. An Interactive Strategic Analysis Famework. Strategic Management Journal, Volume 9, pp. 27-40. 